\title{
The Management of Immovable Property, Resources by the Local Government in Republic Albania
}

\author{
PhD Candidate, Lirika Kutrolli \\ Public Relations Directorate, Council of Ministers \\ Tirana, Albania \\ Ikutrolli@yahoo.com, Mobile phone: 0694068395
}

Doi:10.5901/ajis.2013.v2n8p431

\section{Abstract}

The focus of this presentation will be the important role that local government has in the management of immovable property. The approval of the legal framework by the central government in the last five years in Albania has been carried out taking into consideration the following objectives:

1. The transference and enhancement of the powers pertaining to central government units with the aim of managing immovable property resources by means of leasing, in which third parties are involved. These items of immovable property include forests, meadows, barren land, abandoned plots of land, etc, which have been transferred to the local government units either in use, or as property of these local government units.

2. The transference of those poëers concerning the management of all legal procedures related to the settlement of the legal titles. This has been one of the pressing issues after the year 1991 in the course of the implementation of the land reform. The uncertainty over the legal titles prevents a great amount of the available land from being part of the land market. The pressure - coming from the citizens as ëell as from various international organizations - to reach a solution is very high.

3. Local government powers, aiming at implementing and carrying out the subsidy plan which aims to support the farmers in planting fruit trees and nut trees, in accordance with the international policies concerning the fuller management and exploitation of the arable land.

The issue $i$ focus on in this presentation is: Are there any obstacles to the implementation of these services? Is the legal framework appropriate for their implementation? In this article $i$ have pinpointed current problems, which require that the legislation be reviewed and modified, so as to make possible the use of those powers pertaining to the local government and the fulfillment of the tasks that the local government units need to carry out, in the framework of the decentralization process. Finding the solution to these problems would lead to a sustainable development, which is indispensable considering the globalization issues and EU integration. The decentralization process, aiming at improving the services which have a bearing on the life of the community, demands a higher level of attention.

Keywords: decentralization, leasing, property titles, legislation.

\section{Importance}

The focus of the paper will be the legal analysis and the identification of problems on the management of recources, real estate, namely of the agricultural land. The management remains a challenge for the local government. Policies on protection and management of land, especially agricultural land, play an important economic and environment role and affect the quality of life and biodiversity. ${ }^{1}$

\section{Participating actors}

the administration of local government, local physical and legal entities, foreign ones as lessees, farmers etc.

\section{Research question}

To what extend are local authorities able to carry out legal obligations for the management of real estate recourses and

\footnotetext{
${ }^{1}$ National Report Biodiversity Strategy and Action Plan, Sponsor: Grants Global Environment Facility (GEF) Tirana, Nov 1999
} \{www.scribd.com / ... / Importance-E-ALBANIA-P ... 
what obstacles arise?

\section{Introduction}

The management and the positive use of agricultural land is and will remain a very important task for state structures, as well as for private administrators (physical and legal entities, both domestic and foreign ones), all this for the values of this land.

A variety of tasks have been assigned to Local Government bodies, but management of resourcesremains the most important one. ${ }^{2}$ Management of these assets is a challenge for local governments. ${ }^{3}$ The obligations of these structures include leasing, protection of soil from erosion, clarification of property titles, ${ }^{4}$ supporting farmers and other entities with subsidy schemes for planting etc. ${ }^{5}$ The realization of this challenge requires a qualified, capable, and trained administration in the field of property, with specific topics in the field of property and land laws. Clarity of property titles avoids conflicts of properties, as reality shows us not a very pleasant situation regarding the number of conflicts in our internal courts, where the largest number of cases is about property issues. ${ }^{6}$ Likewise is the situation in the international arena, the European Court of Human Rights, where Albania is in the first place regarding property issues.

\section{Development}

leasing is a right transfered to local government bodies, and not only for those assets which have been transferred to the municipalities / cities as their properties or for use, but also on those assets that have beeb classified as abandoned, but which are private properties (received pursuant to Law 7501/1991 "On Land" and Law nr.8312/1998 "On undivided agricultural land"). This policy aims a positive use of land and the reduction of the unused areas which are included into the category VII to $X$ of the study of fertility. ${ }^{7}$ It improves the management of land and creates opportunities for the expansion of planted areas and for the increase of agricultural production. ${ }^{8}$

There have been approved some Laws and Decisions ${ }^{9}$ of the Council of Ministers for leasing undivided agricultural lands, but as an achivement will be considered Instruction No. 1, dated 18.07.2012. "Lessor authority is the mayor of the area where is the agricultural land. ${ }^{10}$ In this instruction have been foreseen rectrictions too. ${ }^{11}$ According this instruction is allowed the lease of the agricultural land, unless it is used for agricultural activities (point 7). The lease of the agricultural land has been influenced by the sybsidy schemes for farmers. Subsidies are applied to new plantations, for arboriculture and fruit trees, irrigation etc. ${ }^{12}$

The actual problem that impedes the realization of local governmental tasks, is the ambiguity of property titles. In the absence of initial registration of real estate on a national level, the lack of a certificate of ownership, brings even the inability to benefit from the interested parties, to take advantage of the subinvention schemes. At this point, we could have an improved situation, if intervening in legislation, giving people the opportunity to benefit from subinvention schemes to the subjects that did not possess a certificate of ownership, because of the lack of updating the area, so not

\footnotetext{
2 Decision nr.121, dated 17.02.2011; Law No. 10 257, dated 25.03.2010 and many DCM of other laws

${ }^{3}$ Crosscutting Strategy Reform in the area of property rights, the official website of the Ministry of Justice (accessed date 01.12.2012)

${ }^{4}$ World Bank, Status of Land Reform and Property Market Property in Albania, Tirana, 2006, p 30 which stipulates (.... the area is blocked and informal corrupt transactions and will continue to dominate).Reference to the analysis of questionnaires completed by farmers in the coastal area; referring to the interview with the inhabitants of the coastal zone, referred to the Council of Ministers Archives, DM.P practices of different individuals.

5 World Bank, Status of Land Reform and Real Property Market in Albania, Tirana, 2006, pg 26-27

${ }^{6}$ World Bank statistics (2001)

${ }^{7}$ The report accompanying the draft guidance of the Council of Ministers "On the lease of agricultural land, undivided" approved Instruction No. 1, dated 18.07.2012

${ }^{8}$ The official website of the Ministry of Agriculture, published legal and sub-legal acts pertaining scope of administration and land management. Legislative initiatives:

${ }^{9}$ DCM nr.656, dated 28.07.2010 and Law No. 10 263, dated 08.04.2010 "On the use and exploitation of agricultural land for leasing undivided agricultural lands ".

${ }^{10}$ Instruction No. 1, dated 18.07.2012, Chapter I, point 3

11 Instruction No. 1, dated 18.07.2012, Chapter I, Section 5

${ }^{12}$ European Commission, Brussels, 9 November 2010 SEC (2010) 1335 Commission staff working document, Analytical Report accompanying the Commission Communication of the Commission to the European Parliament and the Council
} 
conducting the initial registration area, process and task of the state structures, not having any connection with the individual. In the National Strategy ${ }^{13}$ it is noted that in the coming years the agriculture sector will obtain a great support and will be one of the priorities, as the exploitation of the land according to the purpose of use, increases the economic development and regulates the country's socio-economic rapports. The subinvention subjects not only benefited from tenants of lands that are managed or owned by municipalities / cities, but also from farmers. Albania has 695000 hectares of land, which accounts for about $24 \%$ of its territory. ${ }^{14}$ Of this area, 80\% (561 $000 \mathrm{ha}$ ) belongs to the private sector and $20 \%$ (134 $000 \mathrm{ha}$ ) to state sector.

Uncertainties of property titles, are an obstacle to the accomplishment of providing leased land and at the same time an obstacle to benefit from subinvention scheme. The completion of documents, and the security of ownership issues remain a challenge for governmental policies. The complex nature of the property and the problematics carried over the years, led to developments in the field of legislation, with the purpose of consolidating the documented land and approximation with EU legislation. The uncertainty of property titles, not only hinders the process of leasing agricultural land, but also increases the conflicts and issues that are oriented in domestic and international courts..$^{15}$ The structure that holds all the weight of the realization of this process and the clarification of property titles is Property Titles Verification Commission $\{$ KVTP\} at every Mayor. KVTPV is established the prefect of each county and chaired by the Director of Government Commission, under the authority and direct dependence on the mayor. When given ownership titles are found illegal they are canceled and the land after being state announced, passes onto the municipal administration $\left\{\right.$ local\} which then carry the granting of their rental. ${ }^{16}$ So the clarification of property titles is a very important process, especially in the area of tourism development priority. ${ }^{17}$ Referring land defined by law no. 7665 , dated 21.1.1993 On the development of areas that have tourism", as amended and regulations for its implementation. ${ }^{18}$

This institution carries out its activities in cooperation with local government, municipality, region. There are adopted some legal changes, which show the growth of local governmental powers.

The Cross-section Strategy of the Ministry of Justice Reform in the area of property rights 2012-2020, defined as the obligation to improve the legal framework of the process of reviewing the legal validity of property titles on agricultural lands and the strengthening of cross-institutional coordination in this process. It is anticipated the outcome of the review of legal validity of the agricultural land ownership titles within 2013.

In exercising its powers, local government structures, face obstacles that have to do with the legal space of domestic legislation. In addition, this disorder also brings the non-fulfillment of legal obligations to entities interested in renting. The following analysis is intended to identify the obstacles and problems that exist in the legal framework, as well as the services of the administration of local government structures. In this direction more attribution is required by high education, to broadcast more knowledge to the local administration, throughout staff training courses. ${ }^{19}$ In all the reports of the World Bank, the European Commission Reports, Report on Albania's progress, etc., it is noted that in the field of property attention and much work is necessitated for the accomplishment of any process. To this reality, a vision is needed.

\section{Empirical Analysis}

The study is based on the analysis of the findings after the completion of 200 questionnaires in the field, in the center commune of Bilisht, Devoll district and in the commune of Vaqarr in Tirana district. The purpose of completing the questionnaires, was to identify the progress, results and problems in local government (communes). The questions aimed at getting the farmers' opinion about the services provided by local government. The credibility to these structures, the

\footnotetext{
${ }^{13}$ National Strategy for Development and Integration for the period 2013-2020 (adopted at the meeting of the Strategic Planning Committee, 20 December 2011)

${ }^{14}$ Council of Ministers, the National Plan for the Implementation of the SAA 2012-2015 (adopted in July 2012), the Current Situation.

15 The European Court of Human Rights (case undergrowth, BESHIRI, DRIZA, and others against Albania)

${ }^{16}$ Article 7, paragraph 1 of the same law

${ }^{17}$ Referring land defined by law no. 7665, dated 21.1.1993 "On the development of areas that have tourism", as amended and regulations for its implementation.

${ }^{18}$ Law No. 9948, dated 07.07.2008 "On the legal validity of the establishment of agricultural land ownership titles," Item 3, Article 8, Decree No. 7507, dated 5.06.2012

19 -Nation Strategy for High Education (Higher) - PhD Lirika Kutrolli, International Conference, referred the Topic: "Differentiated Missions in the University Education Institutions" 26-27 October, European University of Tirana
} 
access to resolve problems or complaints with these structures, the identification of outstanding issues related to resource management (public or private ) and the benefit from the subsidies.

\section{Targets}

farmers and entities benefiting from agricultural lands, forests, meadows and pastures. Physical persons and legal entities interested in obtaining rented land from the local government.

\section{Analysis of the findings}

The results are presented graphically for the 19 questions.

Tab.1. Questions on which the following analysisis based upon.

\begin{tabular}{|c|c|c|c|c|c|c|c|}
\hline \multirow{2}{*}{ No. } & \multirow{2}{*}{$\begin{array}{l}\text { The questions that are taken for analysis \{detached from the } \\
\text { questionnaire with } 19 \text { questions\} }\end{array}$} & $\mathrm{Dv}$ & Dv & Dv & $\operatorname{Tr}$ & $\mathrm{Tr}$ & $\mathrm{Tr}$ \\
\hline & & yes & no & - & yes & no & - \\
\hline 1 & $\begin{array}{l}\text { Do you think that the officials were at the appropriate level of education } \\
\text { and training, for the implementation of this law? }\end{array}$ & 14 & 16 & 0 & 14 & 45 & 12 \\
\hline 2 & $\begin{array}{l}\text { Do you think that the institutions have responsibility for not fulfilling legal } \\
\text { documents of agricultural land? }\end{array}$ & 20 & 10 & 0 & 52 & 4 & 4 \\
\hline 3 & $\begin{array}{l}\text { Do you think that the non provision of land with documents has led to } \\
\text { uncertainty and investment barrier }\end{array}$ & 20 & 10 & 0 & 67 & 3 & 1 \\
\hline 4 & $\begin{array}{l}\text { Do you think that the non provision of land with documents has led to } \\
\text { uncertainty and investment barrier by foreigner investments? }\end{array}$ & 26 & 4 & 0 & 57 & 10 & 4 \\
\hline 5 & $\begin{array}{l}\text { Do you think that a part of the surfaces are sold in order to have the } \\
\text { possibility of building (house)? }\end{array}$ & 23 & 7 & 0 & 50 & 8 & 13 \\
\hline 6 & $\begin{array}{l}\text { Do you think that governments during the } 20 \text { years have had their } \\
\text { attention (priority) solve the problem of property in favor of the former } \\
\text { owners? }\end{array}$ & 20 & 10 & 0 & 10 & 39 & 22 \\
\hline 7 & $\begin{array}{l}\text { Do you think that occasionally, legal changes by governments have } \\
\text { happened to help solving the problems of property for individuals, } \\
\text { farmers and former landoëners? }\end{array}$ & 17 & 13 & 0 & 25 & 27 & 19 \\
\hline 8 & $\begin{array}{l}\text { Do you think it is right that many oënership problems, ëhich should be } \\
\text { resolved in court, are being pursued and resolved administratively? }\end{array}$ & 23 & 7 & 0 & 31 & 18 & 22 \\
\hline 9 & $\begin{array}{l}\text { Do you think that there are certain categories of oënership problems, } \\
\text { ëhich can not be resolved due to the lack of sub-legal acts? }\end{array}$ & 23 & 7 & 0 & 44 & 5 & 22 \\
\hline 10 & $\begin{array}{l}\text { Do you think that the Property Verification Commission is conducting the } \\
\text { activities of the courts? }\end{array}$ & 23 & 7 & 0 & 30 & 15 & 26 \\
\hline 11 & $\begin{array}{l}\text { Do you think that the conflict is less existent in northern areas where } \\
\text { most of the agricultural lands are divided according to the old } \\
\text { borderlines? }\end{array}$ & 15 & 15 & 0 & 58 & 5 & 8 \\
\hline 12 & $\begin{array}{l}\text { Do you think that in the state's structures can be found the willingness } \\
\text { by the administration, for the treatment of a complaint? }\end{array}$ & 20 & 10 & 0 & 18 & 42 & 11 \\
\hline 13 & Have you encountered delays for procedures? & 7 & 23 & 0 & 50 & 12 & 9 \\
\hline 14 & $\begin{array}{l}\text { Do you think that the intervention of a friend with influence has created } \\
\text { facilities for pursuing your complaint? }\end{array}$ & 13 & 17 & 0 & 42 & 22 & 7 \\
\hline 15 & Do you think that farmers regularly pay the land tax? & 13 & 17 & 0 & 28 & 36 & 7 \\
\hline 16 & Is the surface of agricultural land preserved from alteration? & 15 & 15 & 0 & 30 & 24 & 17 \\
\hline 17 & Have you benefited from subsides projects by the state? & 18 & 12 & 0 & 5 & 49 & 17 \\
\hline 18 & $\begin{array}{l}\text { Have you registered your property in (Office for Verification and } \\
\text { Preservation of Real Estate)\{ZVRPP\} }\end{array}$ & 23 & 7 & 0 & 34 & 30 & 7 \\
\hline 19 & $\begin{array}{l}\text { Do you overlapping of your property (two owners for the same land or } \\
\text { area)? }\end{array}$ & 9 & 21 & 0 & 30 & 27 & 14 \\
\hline
\end{tabular}


Graph. 1. Graphic presentation of the questionaire data for Center Commune, Devoll district.

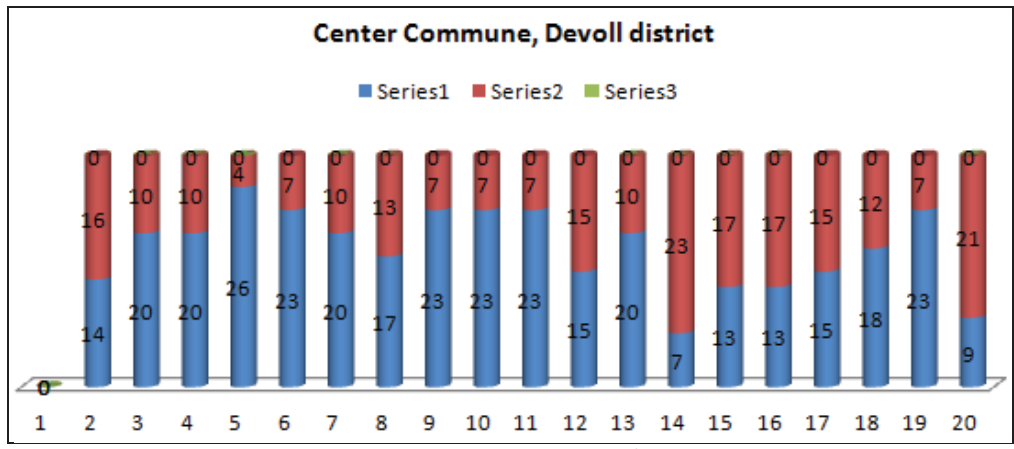

\{note: series 1 is YES; series 2 is NO; series 3 is no related information\}

Graph. 2. Graphic presentation of the questionaire data for Vaqarr Commune, Tirana district.

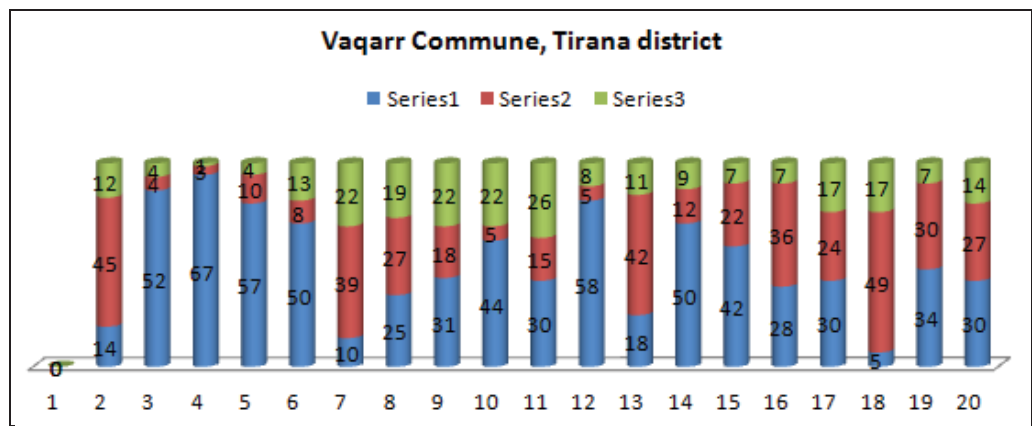

\{note: series 1 is Y ES; series 2 is NO; series 3 is no related information \}

- In the Center Commune, Bilisht, Devoll district, the data show that individuals have more confidence in government policies. They appreciate the existence of institutions that provide solutions regarding the property titles, without having to follow the judicial path. The greater part have registered the properties and do not have any problems ëith the uncertainties of property titles. There are no pproblems with overlapping properties (two subjects claiming to the same property). Noted that service in administration has good quality and the procedures are nots huffled. Over $60 \%$ of respondents have benefited from the schemes of the subsides. Good policies exist to protect the land and resource management. A very small part of the respondents claim to have sold agricultural land. This demonstrates the close connection betëeen farmers and the land in these areas (ëhere the price per $\mathrm{m} 2$ of land currently is not too high).

- In the commune of Vaqarr, the data provide conflicting results with those of the Center Commune in Bilisht. The Trust or Confidence of individuals in the state structures is loëer, they think that the administration services are missing, and they have problems with overlapping titles and a greater part has not registered the property. They havent benefited from the subsides scheme ( only 10\% of respondents have benefited), and they do not think they have enough policies towards the protection and resource management. A great part of respondents claim to have sold agricultural lands, unlike Devoll district. Vaqarr farmers do not show interest in agricultural lands. Given the great price of land in this area, they have increased their interest in selling these lands, moving away from agriculture.

\section{Conclusion}

The comparison of both cases surveyed in this analysis, has helped this study conclude that: closer to the metropol, the price of agricultural land is higher and the interest of farmers to use land for agricultural purposes is lowëer. 
In this regard, the central and the local government policies must guide the growth of interest in agricultural land and limit in maximum the fragmentation in the future of this land. The sales of land for building purpose must be prevented.

Increasing fragmentation, directs the change of use of agricultural land, adversely affects the reduction of production, and prevents the development of agriculture to use mechanized tools. This research found some situations that put subjects-farmers in unfavorable conditions. These problems would be resolved with legal intervention, according to the above suggestions, set during the research.

Defining the solution ëays, delivers a sustainable development, a necessity in the context of globalization and EU integration. Decentralization, in terms of the functions and Local Government direct services to the community, requires attention increasingly.

\section{Recomandations}

- Need to increase the accountability of officials for service delivery.

- Need to conduct field verification in order to identify the various problems.

- Need to identify the reasons for the existence of the problems related to land non-enrollment, or overlapping for residents of the Vaqarr Commune

- To consider the possibility of treatment with subsidies to entities that are not equipped with ownership certificate, applying only Receipt Acts that Land Owned \{AMTP\}.

- Institutional support is required for local government, in order for the legal obligations in relation to resource management of real estate to be carried out, until the initial registration of assets in the republic level is finished.

- The Communes should develop more policies in terms of economic growth, through the realization of planting projects Barren lands, coniferous and medicinal plants. There are a number of plants with high medicinal and economic value, as such, I would mention chestnuts (especially in the mountains).

- Local government bodies should do more in terms of increasing subside projects, but first the ownership titles must be clarified, as a guarantee that positions the individual in favorable conditions to benefit from these grants. The time for clarity of property titles should be from the begining of 2013 to the end, (as determined by the law, should be postphoned because the timeframe is too short, and the legal framework is not yet complete).

- Local government structures should also increase the responsibility for the protection of agricultural land from alteration and damages.

- To have more training for administration related to law enforcement for farmers in relation to their activities in agriculture and arboriculture.

Local government must design projects in the framework of cooperation with the European Union and the World Bank for financial support for the development of programs with specific topics in the field of property, with the communes I municipalities administration employees, developing these training programs-courses in the 12 districts of the Republic of Albania. These projects will equip the local administration, ëith the necessary knowledge for the challenges.

- The culture for the environment and agriculture, should be in the focus of the curricula in primary education onwards.

- The commitment of a particular importance toëards agricultural land, is presented as a necessity, as it provides valuable contributions in the conservation of biodiversity and increasing the quality of human life and the planet.

- Civil society should give its contribution to the development of environmental legislation sectors, forest lands, etc., since the development of agriculture and forestry is the basis of food quality and our lives. This battle should not be considered only of the farmers and local government but of all humanity.

\section{References}

National Report, Strategy and Biodiversity Action Plan Sponsor: Aid Global Environment Facility (GEF) Tirana, Nov 1999 $\{$ www.scribd.com / ... / Importance-E-ALBANIA-P ... $\}$ 
Instruction No. 3, dated 16.05.2007

Archival Fund Council of Ministers, referred to the explanatory memorandum accompanying the draft decision Nr.656, dated 28.07.2010 The Council of Ministers, the National Plan for the Implementation of the SAA 2012-2015 (adopted in July 2012), the current's situation. www.mbumk.gov.al Facilitate farmers by 20-year-old stalemate property rights ...... (eg agriculture minister in parliament)

Referred County Mayors official papers in Albanian Republic, following the queries of this study. They report that there is a lack of documentation.

European Commission since 2010, Brussels, 9 November 2010, SEC (2010) 1335, Commission Staff Working Document, Analytical Report

European Commission, Brussels, 9 November 2010 SEC (2010) 1335 Commission staff working document, analytical report accompanying the Commission Communication to the European Parliament and the Council,

National Plan for the Implementation of the SAA 2012-2015 (adopted in July 2012

Law No. 9948, dated 7.7.2008 "On the legal validity of the establishment of agricultural land ownership titles", as amended, (promulgated by Decree No. 7507, dated 5.06.2012)

Law No. 58/2012; DCM No. 185, dated 13.03.2012; DCM No. 196, dated 13.03.2012

The legal framework on the transfer of forests and pastures, to the local government and legal frameëork on abandoned land management by local government.

European Court of Human Rights (case undergrowth, Basheer, and others, against Albania)

World Bank, the second document \{lnformation Governance in the protection of rights over immovable property in Albania: constant challenge\} second edition April 2012 